\title{
Development of Mathematics Learning Devices Based on Guided Discovery Learning Models and Focusing on Students' Mathematical Power at SMP Istiqlal Delitua
}

\author{
Julian A. Hartono ${ }^{1}$, Ida Karnasih' ${ }^{2}$, Dian Armanto ${ }^{3}$ \\ ${ }^{1}$ Postgraduate Program in Mathematics Education Department, Universitas Negeri Medan Indonesia \\ ${ }^{2,3}$ Mathematics Education Department, Universitas Negeri Medan, Indonesia
}

\begin{abstract}
This developmental research aimed to analyze the validity of learning devices, practicality and effectiveness of the devices, as well as student responses to the use of Guided Discovery learning based learning devices that focusing on Mathematical Power. Data collecting was done by using a validation questionnaire with the observation method, a control problem ability test with mathematical power, and student questionnaire responses to guided discovery-based learning tools. Data analysis used qualitative and quantitative descriptive techniques. Testing of research instruments was carried out at SMP Istiqlal Delitua. The results of the analysis of the validity of the equipment showed that the total equipment was declared valid with an average level of validity of 4, 73 very good criteria. The result of the practicality test showed that the device was stated to be very practical with the proportion of practicality level of $89.94 \%$. To test the effectiveness that the learning device was declared effective with the proportion of effectiveness of $86.49 \%$, with Minimum Completeness Criteria achieved $89.29 \%$ of students completed, and $10.17 \%$ of students not completed. Learning objectives are achieved with the average level of achievement of goals was $88.13 \%$, and students' responses to the feasibility of the devices getting an average total presentation of $94.9 \%$ with very good criteria. The results of the test of the ability of mathematical problems obtained an average value of 79.00 with a good predicate and a standard deviation of 9.76 , and the test reliability coefficient of 0.5714 in the moderate category. Thus it can be concluded the Guided Discovery Learning device was valid, practical, and effective, and the student's response to the appropriateness of the device was in very good criteria.
\end{abstract}

Keywords mathematical power; learning tools; device development model 4D thiagarajan; social arithmetic

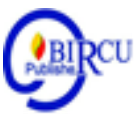

\section{Introduction}

The current reform of mathematics education in accordance with the vision of $21 \mathrm{st}$ century mathematics education requires developing mathematical power for each child. As stated by NCTM in the following statement, that: Mathematics education reform today is focused on the development of "mathematical power" of each child. NCTM believes it can be developed in children who are very young. (NCTM, 1989, p. 5). To realize this vision, NCTM recommends that all aspects of school mathematics such as: the content of the material, learning and assessment need to be changed to lead to a systematic foundation towards the achievement of mathematical power. NCTM (1989) defines that mathematical power. 
"Demonstrating the individual ability needed to explore, predict and reason logically, as well as the ability to use various mathematical methods efficiently to solve non-routine a problem, this idea is based on the fact that mathematics is more than a set of concepts and skills that must be mastered. It includes methods of inquiry and reasoning, communication tools, and understanding of context. In addition, for each individual it involves the development of personal self-confidence" (NCTM, 1989).

Kusmaryono, (2014) states that the development of students' mathematical power is an integral part of the development of a teacher's professional competence, where teachers must try to increase mathematical power which affects how individuals process and learn to acquire knowledge, skills, and attitudes that will be reflected in daily behavior and serve to motivate, and stimulate appreciation of the complexities of student success in interdisciplinary studies. Given the importance of mathematical power, NCTM (1989) states that in learning activities teachers are expected to train students to achieve mathematical power. Teachers must train themselves to understand what mathematical power is and how to improve students' mathematical power through meaningful learning. In learning mathematics it is necessary to create situations where students can be active, creative and responsive. When studying mathematics, students must build knowledge for themselves. The process of building knowledge can only be done by exploring, justifying, describing, discussing, describing, investigating, and solving problems (Countryman, 1992).

Parker (2014) states that mathematics teachers have a responsibility to help all students build mathematical power and mathematical dispositions about the knowledge needed to live successfully in a complex and rapidly changing world. To meet the challenges of the 21 st century, students need mathematical power, a positive disposition towards mathematics (curiosity and self-confidence), has facilities with a mathematical investigation process (problem solving, reasoning and communication), and wellconnected mathematical knowledge (understanding mathematical concepts, mathematical procedures and mathematical formulas) and improve the meta-cognitive capabilities (Depdiknas, 2012)

One of the problems faced by mathematics education in Indonesia, which is happened at SMP Istiqlal Delitua, is the problem of the low quality of the learning process where students are less motivated to develop their thinking skills. The low quality of learning carried out by the teacher and researcher with the solution is only through the use of learning models, approaches, or methods but it does not reveal the students' internal factors more deeply.

The low quality of mathematics education in schools in Indonesia is evident from the existence of Indonesian students' mathematical abilities at the international level, where the results of the 2012 Program for International Study Assessment (PISA) survey showed that Indonesian students' mathematical abilities rank 64 out of 65 countries (PISA 2012 results). Various internal aspects that lead to low math skills are due to the fact that the curriculum used in Indonesia is not in accordance with the assessment given in TIMMS and PISA. In addition, the learning process and students' math skills are still low such that improvements need to be made on the quality of student learning, students' self-confidence in learning mathematics, a sense of having knowledge and students' mathematics skills. This is very necessary to prepare the student's career and life in the future as agents of change. 


\section{Review of Literatures}

The 2013 curriculum has recommended applying a scientific learning model in mathematics learning (Depdiknas, 2012) with the aim of getting children to learn to innovate and develop ideas and cognitive skills and develop associative thinking skills. Besides that, it also trains behavioral skills, namely, asking, making observations, and conducting experiments, using scientific learning through experiments, conducting experiments, inventions and making predictions in accordance with the goals in achieving student mathematical power. The conception of the scientific approach applied to learning includes components: observing, asking, giving reasons, trying, creating, presenting, and communicating ideas that are very important in learning mathematics (Kemendikbud, 2013). This is in accordance with the demands of reform in mathematics education towards the development of mathematical power of students. Guided discovery learning model as a scientific model which is recommended in the 2013 Korriculum (Depdiknas, 2015) is in accordance with Social Arithmetic learning material with a focus on mathematical power. With Guided Discovery students learn by discovering their own concepts and principles and solving problems through their own thinking, making conjectures from solving problems, and solving problems in their own way. The learning process with this model which is accompanied by valid learning devices will be able to achieve the learning objectives that have been planned both in the aspects of student knowledge, attitudes and skills. The 2013 new curriculum reform was developed based on the consideration of the situation and conditions and the implementation of the previous curriculum, where the government has determined mathematics learning at the Elementary and Middle Level Education levels, which still sets mathematics learning objectives in the 2004 Curriculum or KTSP 2006, namely:

"(1) Train the way of thinking and reasoning in drawing conclusions, for example through research activities, experiments, showing similarities, differences, and inconsistencies; (2) Developing creative activities that involve imagination, intuition and discovery, by developing divergent, original thinking, curiosity, making predictions and guesses, and experimenting; (3) Develop problem-solving abilities; (4) Developing the ability to convey information or communicate ideas through oral conversation, notes, charts, diagrams and explaining ideas. " (Depdiknas, 2012).

By understanding the above objectives, it can be seen that the objectives of learning mathematics have led to active student learning with mastery of five process standards, namely the ability to reason, communicate, connect knowledge, and solve problems and represent ideas. It means that since the 2004, Indonesian curriculum has started to lead to development of mathematical power. Learning is carried out according to the Ministry of National Education (2012), the development of learning devices is the responsibility of teachers in schools, because teacher's creativity in developing learning devices will result in meaningful learning activities. The learning device is the most important component that must be prepared by the teacher before carrying out the learning process. Learning devices should not only provide material instantly, but be able to lead students to the ability to understand concepts and principles being learned. This ability is useful for improving students' mathematical problem solving abilities.

Learning achievement and the ability of students to solve problems very much depends on how they get their learning and how the tests are given to students. The 
student's ability to answer correctly indicates the level student mastery of the material being taught and the specified competency indicators. In learning Social Arithmetic in Class VII, the results of interviews showed that students had very low mathematical problem solving abilities. Students have difficulties mastering the material being studied and they have not been able to understand the concepts to solve problems. Errors in solving math problems often occur and it is revealed that the factors that cause students to make mistakes in solving math problems are the students' lack of understanding in interpreting information about problems in the form of mathematical arithmetic operations. Difficulties in applying concepts to solve problems and procedural difficulties, namely difficulties in presenting the steps in solving problems, and difficulties in developing problem solving strategies still occur in students. Therefore, in learning mathematics, teachers need to pay more attention to the difficulties experienced by students and try to solve problems and find solutions. The main thing in solving the problem is that the teacher must develop learning tools that support the achievement of the specified learning objectives including LKPD and develop problems that are interesting, challenging and enjoyable for students to solve. Selection of learning models, media or tools that are suitable for the material and conditions of student readiness must be designed. Evaluation instruments must also be developed according to the demands of the 2013 Curriculum, namely evaluating processes and products with the use of portfolios and authentic assessment (Depdikbud, 2012).

Problem solving ability is a very important ability in learning mathematics because it will help mastering meaningful concepts and help solve problem-solving tasks through linking mathematical concepts with concepts in other disciplines. Mathematical power is very important in problem solving. In order for students to have mathematical power or power, they must be taught by the teacher as critical, creative and innovative thinkers, who can realize and simulate these qualities in every phase of teaching. The condition that must be improved is the planned mathematics learning process to develop students' mathematical thinking power, so that it makes learning activities meaningful (Kusmaryono, 2014).

One of the contributions of mathematical power is its role in developing students' mathematical problem-solving abilities. NCTM, (1989) states that problem solving must underlie all aspects of mathematics teaching in order to provide students with experience of mathematical power in the world around them. Furthermore, NCTM (2000) in the standard principle for problem solving has stipulated that learning programs from prekindergarten to grade 12 should allow every student to; (a) Build new mathematical knowledge through problem solving; (b) Solve a problem arises in mathematics and in other contexts; (c) Implement and adapt various appropriate strategies to solve problems; (d) Monitor and reflect on the process of solving mathematical problems. During problem solving activities, students often reflect on mathematical ideas in tasks, formulating ideas are more likely to be assimilated with their previous knowledge during activities (Van de Walle et al., 2009). When solving useful problems, students are building and restructuring their own knowledge and will be actively involved in all standard NTCM processes: problem solving, reasoning, problem-solving communication are used effectively in the classroom, which in turn develop students' mathematical power as described by NCTM (2000). According to Pohan (2020) One of the mathematical skills that students must possess and achieve is problem solving. Problem solving is very close to mathematical characteristics. The low ability of students to solve mathematical problems is influenced by several factors, both external and internal factors (Wahyuddin in Irhamna, 2020). 


\section{Research Methods}

This study develops learning tools by referring to the research on the device development model suggested by Thiagarajan, Semmel, and Semmel (1974), namely the 4D model which consists of the following 4 stages: The define stage, Design stage , Develop stage, and Disseminate stage. The main objective of this research is to produce learning devices based on the Guided Discovery Learning Model that focuses Mathematical Power which is valid, practical and effective. The devices developed are Teacher's Manual, Student Book, Lesson Plan, Students' Worksheets, and Evaluation Instruments. This research was carried out for Grade VII SMP Istiqlal Delitua. Testing of valid devices was in that school involving 28 students. The learning trials of the devices is carried out using online method conducted for 4 meetings ( 4 x 1 hour) in which teachers teach at schools and students learn at home by using Hand phone (WA).

The type of data in this research is qualitative and quantitative data. The instruments used in this study included: devices validation sheets, student activity observation sheets, problem solving ability tests and student response questionnaires to the use of Guided Discovery learning of Social Arithmetic materials. In this study, the focus of the assessment was mathematical problem solving ability associated with mathematical power. The data analysis used in this study was the analysis of the devices review, the expert validation analysis, the problem solving ability test analysis, and the student response analysis. The data analysis technique used is descriptive qualitative and quantitative analysis.

\section{Results and Discussion}

The results included in this report are in accordance with the stages of the research carried out, namely the device development stage, the device validation stage, and the device testing stage. The following shows the results of the research at each stage.

\subsection{Discussion}

\section{a. Development Process}

The results of the development research explain the development with 4 stages, namely the definition stage, design stage, the development stage, and the dissemination stage.

\subsection{Definition Stage (Define)}

At the defining stage, five things were analyzed: preliminary and final analysis, student analysis, concept analysis, task analysis, and formulation of learning objectives. At this stage, the curriculum and the problems that occurred in SMP Istiqlal Delitua were first examined in relation to this research. Also analyzed the condition and situation of students regarding their initial academic and affective abilities as well as mathematical skills possessed by students in studying Social Arithmetic material. The mathematical concepts to be studied and the tasks discussed and the objectives to be achieved were discussed at the beginning of this study. This initial discussion was intended to provide a direction for the development of the devices to be carried out and what goals to achieve. The learning model chosen is the Guided Discovery Learning Model With a focus on the mathematical power of students who are considered suitable for learning Social Arithmetic with a focus on mathematical power. 


\section{b. Design Stage (Design)}

At the design stage, it is explained the activities of selecting learning materials, determining the learning model with a scientific approach, the process of compiling tests, determining the media and determining the format of the device. The material chosen for the development of this devices is Social Arithmetic material with Core Competencies, Basic Competency, indicators and learning objectives adapted from the 2013 Curriculum. The mathematical power test being tested was mathematical problems solving ability associated with standard processes of reasoning, communication, representation, and connection skills in problem solving. In this study, the media used were objects around students both at home and at school that are suitable for Social Arithmetic, the format of the device was selected according to the format developed, for example the format of content, language, illustrations, use of images, graphics, selection of colors and shapes and so on. The results of the selected design are used to design tools for learning Social Arithmetic with the Guided Discovery learning model.

\section{b. Development Stage (Develop)}

At this development stage the activity begins with compiling learning devices in the form of a Teacher's Guide Book , Student Book , Lesson Plan, Student Activity Sheet , Problem Solving Ability Test and Evaluation Instrument. . The results obtained in the form of criticism and suggestions were used to revise or improve the learning device before the device was tried out. Validation activities are carried out by providing device product scripts and validation sheets to the validator. Devices that are already valid are then tried out in Grade VII to test their practicality, effectiveness and see student responses of the devices used by students, After all the devices were valid, practical and effective and getting a positive response from students, the devices then were applied in a real class. The effectiveness of the device is seen from the fulfillment of the students 'minimum completeness criteria, the achievement of learning objectives, and the effectiveness of using learning time, as well as students' positive responses to the learning being carried out. By fulfilling all these effectiveness criteria, the device can be used in a wider class.

\section{c. Dissemination Stage}

The purpose of the dissemination stage is to disseminate the results of research products in the form of valid learning tools that have been tested in limited groups. In the dissemination stage, the products from the results of the development of the tools developed will be disseminated to the public or schools and mathematics teachers. In this study, dissemination will be limited to publishing articles in the Mathematics Education Journal.

\section{d. Validation of the Devices}

Device validation begins with validating all the tools that have been developed, namely the Teacher's Guide Book, Student Book, Lesson Plan, Student Worksheets, and Evaluation Instruments. Validation for each researcher is carried out according to predetermined indicators. The validation instrument is a validation sheet which has been arranged according to the aspects assessed including aspects of format, language, content, illustrations. Some devices are validated based on shape, arrangement, image, color and so on. The device was validated using a validation sheet provided by three mathematics education experts and two Istiqlal Delitua Junior High School teachers. The validation result data is analyzed and concluded by the researcher. From the results of the validation 
analysis, it is summarized that the overall validation results of all the tools that have been developed and validation results are obtained. Table 1 shows the results of the validation of each device developed with an average score of $>4.0$ in the "valid" category.

Table 1. Learning Devices Validation Results Based on Guided Discovery Learning

\begin{tabular}{|l|l|c|c|}
\hline No & \multicolumn{1}{|c|}{ Devices } & $\begin{array}{c}\text { Average } \\
\text { Score of } \\
\text { Validation }\end{array}$ & $\begin{array}{c}\text { Level of } \\
\text { Validation }\end{array}$ \\
\hline 1 & Teacher's Manual & 4,68 & Valid \\
\hline 2 & Student Book & 4,67 & Valid \\
\hline 3 & Lesson Plan & 4,76 & Valid \\
\hline 4 & Student Worksheets & 4,73 & Valid \\
\hline 5 & Evaluation Instrumen & 4,25 & Valid \\
\hline \multicolumn{2}{|l|}{ Rata-rata Total } & $\mathbf{4 , 6 1}$ & Valid \\
\hline
\end{tabular}

Criteria of Validity :

$1 \leq \mathrm{Va}<2 \quad$ : Not Valid

$2 \leq \mathrm{Va}<3 \quad$ : Less valid

$3 \leq \mathrm{Va}<4 \quad$ : Enough valid

$4 \leq \mathrm{Va}<5 \quad$ : Valid

$\mathrm{Va}=5 \quad$ : Very valid

From the results of device validation, input or suggestions are obtained to produce a proper device. After the instrument was reviewed, it was revised and then based on the validation results it was used for limited trials.

\section{e. Teacher's Guide Book Validation Results}

For the Teacher's Manual the components assessed were: format, language, illustrations and content. In terms of format, it was assessed the clarity of material distribution, attractiveness and spatial layout as well as the suitability of text and illustrations. In terms of language, it was assessed that the correctness of grammar, suitability and sentence structure assessed. In terms of illustration, it was assessed the illustrative support for concept explanation, visual stimulation, clear appearance and easiness to understand. In terms of content, the correctness of the material was assessed and its suitability with competence. In terms of format, language, illustration and content, the validators gave an average score of 4.50, 4.40, 4.48, and 4.44, respectively. The overall average score for the assessment of the teacher's manual is in the "valid" criteria with a score of 4.38. The five validators concluded that the teacher's manual can be used with minor revisions. The validators' assessment, corrections, criticisms, and suggestions were obtained which were used as material for consideration in revising the teacher manual.

\section{f. Student Book Validation Results}

The assessment conducted by the validator on the Student Book includes indicators: format, language, illustrations, content. In terms of format, it was assessed the clarity of material distribution, attractiveness and spatial layout, and the suitability of text and illustrations. In terms of language, the correctness of grammar, sentence suitability and 
sentence structure is assessed. In terms of illustration, it was assessed that illustrative support for conceptual explanation, visual stimulation, clarity of appearance and ease of understanding. In terms of content, it was assessed according to basic competencies, order of material and suitability of problems, steps for using props. In terms of format the validator gave an average score of 4.50, in terms of language the validator gives an average value of 4.54 , in terms of illustration the validator gave an average score of 4.50 . Based on the results of the validation, the average score for each aspect of the assessment of the five validators was at a value of $\geq 4.0$ with the criteria "valid". The overall average score on the student book assessment is in the "valid" criteria, which was 4.45. The five validators concluded that student textbooks could be used with minor revisions.

\section{g. Lesson Plan Validation Results}

The validator's assessment of the Learning Implementation Plan (RPP) includes indicators: format, content, and language. In terms of format, it is assessed that the clarity of the distribution of the material on the layout of the room and images and sizes is assessed. In terms of content, it is assessed the suitability of the content with the 2013 curriculum competency standards, the choice of strategies, and teacher activities and student activities and conformity to the Guided Discovery learning model. In terms of format the validator gave an average value of 4.50. In terms of content, the validator gave an average value of 4.54. In terms of language, the validator gave an average value of 4.50 . It turns out that the results of the validation showed that the average score of each aspect of the five validators were $\geq 4.0$ with the criteria "valid". The overall average score against the Lesson Plan assessment was 4.52 with "valid" criteria. The five validators concluded that the lesson plan can be used with minor revisions. From the validator's assessment, corrections, criticisms, and suggestions were obtained which were used as material for consideration in revising the lesson plan.

\section{h. Worksheets Validation Results}

The validator's assessment of the Worksheets included indicators: format, content, and language. In terms of format, it was assessed that the clarity of the distribution of the material on the layout of the space, images and sizes were assessed. In terms of content, it was assessed the suitability of the content with the 2013 curriculum competency standards, the selection of strategies, and teacher activities and student activities and conformity to the Guided Discovery learning model. In terms of language, the correctness of grammar was assessed

\section{i. Mathematical problem solving abilities Validation Results}

The developed mathematical (Problem Solving Ability Test was validated by five validators. The validator evaluated the test based on the indicators using the validation sheet based on content, construction, language, level of difficulty, and the time use of the test. The results of the assessment were then revised based on the validator's suggestions, and then the valid test can be used in learning trials. The results of the mathematical TKPM validation can be shown in Table 2 . 
Table. 2. Validity of Ability Test Items Mathematical Problem Solving

\begin{tabular}{|c|c|c|c|c|}
\hline Item tes & $\boldsymbol{r}_{\boldsymbol{x y}}$ & $\boldsymbol{t}_{\text {count }}$ & $\boldsymbol{t}_{\text {table }}$ & Interpretation \\
\hline 1 & 0,758 & 5,496 & 1,706 & Valid \\
\hline 2 & 0,760 & 5,755 & 1,706 & Valid \\
\hline 3 & 0,696 & 4,378 & 1,706 & Valid \\
\hline 4 & 0,735 & 5,179 & 1,706 & Valid \\
\hline
\end{tabular}

Table 2 shows the test results of the research instrument test of mathematical problem solving abilities for 4 (four) essay questions with a significant level of $5 \%$ and $\mathrm{dk}$ $=28,\left(t_{\text {table }}=1.706\right)$. If referring to the testing criteria, namely $t_{\text {count }}>t_{\text {table }}$, the mathematical problem solving ability test is declared valid. The total validity average value of 4.30 with a percentage of validity value $83.3 \%$. From the results of the data analysis, it was found that the average correlation coefficient of the four item tests was 0.737 a high validity.

\section{j. Results of Reliability of Posttest}

The reliability of the instrument was used to determine the determination of the test results. After calculating using the Cronbach Alfa formula, the number of items is 4 , the total variance of the score for each item is 28.988 , and the total variance is 52.667. Based on the results of reliability calculations using Microsoft Excel, the reliability coefficient is 0.5741. From the results obtained, it can be concluded that the posttest problem of mathematical solving ability has a reliability coefficient of moderate degree of reliability.

\section{k. Devices Trial Process}

\section{Practicality Test of Learning Devices}

Practicality test tests the device whether the learning device is practical or easy to use by users. In this questionnaire, questions were asked about students' interest in the device, student responses to device displays, student opinions about the use of the Guided Discovery Approach and its tools.

Table 3. Table of Practicality of Learning Devices

\begin{tabular}{|c|l|c|c|}
\hline NO & \multicolumn{1}{|c|}{ Practicality Variable } & $\begin{array}{c}\text { Value of } \\
\text { the } \\
\text { Practicality }\end{array}$ & Criterion \\
\hline 1 & $\begin{array}{l}\text { Student interest in guided } \\
\text { discovery based learning tools }\end{array}$ & $88.16 \%$ & $\begin{array}{c}\text { Very } \\
\text { practical }\end{array}$ \\
\hline 2 & $\begin{array}{l}\text { Student responses to the } \\
\text { appearance of the learning device }\end{array}$ & $87.22 \%$ & $\begin{array}{c}\text { Very } \\
\text { practical }\end{array}$ \\
\hline 3 & $\begin{array}{l}\text { Student responses to the use of } \\
\text { Guided Discovery Approach in } \\
\text { learning }\end{array}$ & $86.43 \%$ & $\begin{array}{c}\text { Very } \\
\text { practical }\end{array}$ \\
\hline 4 & $\begin{array}{l}\text { Student responses to the test of } \\
\text { students' mathematical problem } \\
\text { solving abilities given }\end{array}$ & $91.43 \%$ & $\begin{array}{c}\text { Very } \\
\text { practical }\end{array}$ \\
\hline $\mathbf{5}$ & $\begin{array}{l}\text { Average } \\
\mathbf{2}\end{array}$ & $\begin{array}{c}\text { Very } \\
\text { practical }\end{array}$ \\
\hline
\end{tabular}


After the entire devices were declared valid, then it was tested in a limited class to test the practicality of Guided Discovery Learning based tools with a focus on mathematical power. From the results of the analysis, all variables obtained a practical value reaching an average of $88.13 \%>80 \%$, which means that in total the students' positive responses to the use of guided discovery-based learning models with a focus on mathematical power. Based on the table, it can be seen that the total percentage of the assessment of each component in the limited group practicality test is very practical, and the practicality value is very high.

\section{The Effectiveness of Learning Device Test Results}

To test the effectiveness, it can be seen from three things, namely: (1) looking at the percentage of Minimum Completeness Criteria (KKM) of students' problem solving abilities, (2) achieving learning objectives and (3) using effective time. The following are the results of the posttest students' problem solving abilities.

Table 4. Posttest Results of Problem Solving Ability and Student Learning Completeness

\begin{tabular}{|c|c|c|c|c|c|}
\hline No. & $\begin{array}{c}\text { Value } \\
\text { Range }\end{array}$ & $\begin{array}{c}\text { Number of } \\
\text { Students }\end{array}$ & $\begin{array}{c}\text { Percentage } \\
(\boldsymbol{\%})\end{array}$ & $\begin{array}{c}\text { By } \\
\text { Letter }\end{array}$ & Category \\
\hline 1 & $86-100$ & 6 & 21,42 & A & Complete \\
\hline 2 & $76-85$ & 19 & 67,85 & B & Complete \\
\hline 3 & $66-75$ & 2 & 06,75 & C & $\begin{array}{c}\text { Not } \\
\text { Complete }\end{array}$ \\
\hline 4 & $0-65$ & 1 & 03,38 & D & $\begin{array}{c}\text { Not } \\
\text { Complete }\end{array}$ \\
\hline & Total & $\mathbf{2 8}$ & $\mathbf{1 0 0 , 0 0}$ & & Complete \\
\hline
\end{tabular}

3. Minimum Completeness Criteria Results

Learning tools are said to be effective if $85 \%$ of students score $>75$ (CCR). Table 3 above shows the results of the problem solving ability test obtained that 28 students $(89.27 \%)$ who took the test was complete It means students complete $>85 \%$, and 3 students $(10,73 \%)$ incomplete. From these results it can be concluded that this problemsolving ability test has met the CCR criteria.

The result of analyzes of the Problem Solving Ability Test showed result of the average score was 79,00 with standard deviation 10,96. Based on the criteria given, it could be concluded that the mastery level of the student test was achieved with category high level.

\section{The Results of Achievement of Learning Objectives}

The analysis of the achievement of the learning objectives was carried out to determine the percentage of achievement of the learning objectives for each postest item of the mathematical problem solving ability. The level and percentage of achievement of post-test learning objectives of mathematical problem solving abilities in the trial according to the results of the analysis obtained the results of learning goal 1 was obtained by $86.65 \%$, the achievement of learning objectives 2 was obtained by $85.83 \%$, the achievement of learning goal 3 was obtained by $87.5 \%$, the achievement of learning objectives 4 was obtained at $85.50 \%$. the achievement of learning objectives 5 was obtained $85.50 \%$. The overall average achieved the percentage of goal achievement was 
$85.32 \%$. In accordance with the criteria for the achievement of learning objectives, it is said that the learning objectives are achieved with the criteria $\geq 75 \%$ of the maximum score achieved for each aspect. Thus the learning objectives in the trial have been achieved. The results of this overall analysis indicate that the learning objectives are achieved with good criteria.

\section{Time Usage}

In terms of the use of learning time, the results of observations show that the time used has met the ideal time criteria, where learning is carried out four meetings with a time of 4 $\mathrm{x} 1$ hour using the online method. From the results of observations, there are no problems with the use of time.

From the three results of the analysis above, it can be concluded that the devices developed have met the criteria for being effective.

\section{Student Responses to Guided Discovery Learning}

Student response questionnaires answered four aspects of guided discovery learning and its tools and classroom management. Question concerning the pleasure of learning given, about the novelty of the material being taught, interest in following lessons, and student interest in the device presented. For the aspect of students' enjoyment of learning and its devices, it was obtained an average of $90.00 \%$ in the very good category. For the aspect of student response to the novelty of the learning component, the student response reached an average percentage of $87.00 \%$ which was in the very good category. In the aspect of student interest in participating in learning activities, of the 28 students, 26 students (93.26\%) expressed interest, while 2 students $(6.74 \%)$ were not interested. For the aspect of student responses to the use of language in the Student Book and LKPD, the results of the student response were $96.66 \%$ understood the language in the Student Book and $100 \%$ understood the language used in the LKPD.

\subsection{Discussion}

Developing students' mathematical power is an integral part of developing a teacher's professional competence. Mathematical power affects how individuals process and learning outcomes to acquire knowledge, skills and attitudes which will be reflected in daily behavior and serve to motivate, stimulate appreciation of the complexity of student success in interdisciplinary learning. Teachers should design and develop learning tools and carry out mathematics learning to develop students' mathematical power through the application of innovative and creative scientific learning as well as assess integrated mathematical power in problem solving abilities. Guided Discovery Learning has made students more independent and active in thinking in their learning, but some students are still not able to understand the concepts to solve problems and have not fully mastered problem solving skills. In solving problems, some students make mistakes in solving mathematical problems because of their lack of understanding in interpreting information about problems in the form of mathematical operations. Conceptual difficulties, namely difficulties in applying concepts to solve problems, and procedural difficulties, namely difficulty in presenting the steps in solving problems, as well as difficulties in developing problem solving strategies effectively and efficiently still occur in students. The assessment of mathematical power must cover all aspects identified in this mathematical power standard and be integrated into its mathematical ability. Assessment of the strength of mathematics is an assessment of competency assessments that is not separated from one 
another, but the emphasis must remain clear that the strength of mathematics concerns all aspects of mathematical knowledge and its integration (Kusmaryono, 2014).

\section{Conclusion}

From the results of the research that has been done, it is concluded that the learning device developed based on the Guided Invention Model and focuses on Mathematical Power: (1) has met the validity criteria based on the results of expert validation with an average total validation of $83.72 \%$ in the valid category. All devices meet the valid criteria, the average overall validity score is 4.73 with very good category. (2) It has met the criteria of practicality an average of total practicality of $89.94 \%$. with very good category; (3) It has met the effectiveness criteria in terms of: (a) student learning completeness has been achieved $89.28 \%$ of students complete and $10.72 \%$ not complete, (b) the achievement of the goal has met the requirements achieved with a percentage of $85.32 \%$; (c) The learning time has met the ideal time criteria; (d) has shown a positive response for all aspects assessed; (e) The test of mathematical problem solving ability has reached an average score of 79.00 in the good category with a standard deviation of 9.76. From all results of the analyses, it can be concluded that the development of learning devices using Guided Discovery Learning with focusing on Mathematical power has met the criteria of valid, practice, effective, and get positive srespons from students.

\section{References}

Borthick, A. Faye \& Donald R. Jones (2000). The Motivation for Collaborative Discovery Learning Online and Its Application in an Information Systems Assurance Course, Issues in Accounting Education, 15 (2). [2].

Countryman. 1992. Hakikat Pembelajaran Matematika. Surakarta: Depdiknas

Depdiknas, 2006. Permendiknas Nomor 22 Tahun 2006 Tentang Standar Isi Sekolah Menengah Atas. Jakarta: Depdiknas

Curriculum and Evaluation Standards for School Mathematics: A Vision of mathematical Power and Apreciation for All. www.sde.ct.gov/sde/lib/.../mathgd_chpt1.pd

Depdiknas. 2006. Peraturan Menteri Pendidikan Nasional Nomor 22 Tahun 2006 Tentang Standar Isi Sekolah Menengah Atas. Jakarta: Depdiknas

Depdiknas, 2012. Pengembangan Kurikulum 2013, Jakarta: Depdiknas.

Depdiknas, 2015. Revisi Kurikulum 2013, Jakarta: Depdiknas.

Irhamna, Amry, Z., and Syahputra, H. (2020). Contribution of Mathematical Anxiety, Learning Motivation and Self-Confidence to Student's Mathematical Problem Solving. Budapest International Research and Critics in Linguistics and Education (BirLE) Journal Vol 3 (4): 1759-1772.

Kementerian Pendidikan dan Kebudayaan. 2011. Survei International PISA. Online. (http://litbang.kemdikbud.go.id/index.php/survei-internasional-timss, diakses 10 Agustus 2019.

Kemendikbud 2013. Kurikulum 2013 : Konsep Dasar Pendekatan Saintifik DEPDIKNAS Jakarta.

Kusmaryono, I. 2014. The Importance of Mathematical Power in Mathematics Learning. Paper presented in International Conference on Mathematics, Science, and Education, Universitas Negeri Semarang (UNES), diakses pada 1 Juli 2019 https://www.researchgate.net/publication/303459705 
(http/p4tkmatematika.org/downloads/ppp/PPP Penemuan-terbimbing.pdf,

National Council of Teacher of Mathematics. (1989). Curriculum and Evaluation Standards for School Mathematics. Reston. VA: NCTM

National Council of Teacher of Mathematics. 1991. Professional Standards for Teaching Mathematics. Reaston. VA: NCTM

National Council of Teacher of Mathematics. 2000. Assessment Standards for School Mathematics. Reston. VA: NCTM

National Council of Teacher of Mathematics. 2000. Teaching Standards for School Mathematics. Reston. VA: NCTM

Parker, R.E. 1995. Mathematical power: Lessons from a classroom. Heinemann

Inc, ABD (1)

Permendikbud. 2013. Peraturan Menteri Pendidikan dan Kebudayaan

Nomor 54, Tahun 2013, tentang Standar Proses Pendidikan Dasar dan Menengah.

Permendikbud. 2013. Peraturan Menteri Pendidikan dan Kebudayaan Nomor 67, Tahun 2013, tentang Standar Proses Pendidikan Dasar dan Menengah.

Pohan, A.M., Asmin, and Menanti. (2020). The Effect of Problem Based Learning and Learning Motivation of Mathematical Problem Solving Skills of Class 5 Students at SDN 0407 Mondang. Budapest International Research and Critics in Linguistics and Education (BirLE) Journal Vol 3 (1): 531-539.

Thiagarajan S., Semmel D., \& Semmel. M. I. 1974. Intructional Development For Training Teachers Of Exceptional Children: A Sourcebook. Minneapolis: Central for Innovation on Teaching the Handicaped.

Trianto. 2007. Model Pembelajaran Terpadu dalam Teori dan Praktek. Jakarta: Prestasi Pustaka Publisher.

Trianto, 2011. Mendesain Model-Model Pembelajaran inovatif-Progresif. Jakarta: Kencana Prenada Media Group.

Van de Walle, J. A.. 2006. Elementary and Middle School Mathematics. Teaching Developmetally, Sixth Edition. Virgi. 